\title{
MODELING AND FORECASTING OF THE INTEGRATED INDEX OF INNOVATION ACTIVITY OF REGIONS
}

\author{
Olha Popelo ${ }^{1}$, Svitlana Tulchynska ${ }^{2}$, Rostislav Tulchynckiy ${ }^{3}$, Semen Khanin $^{4}$, Alla Hrechko $^{5}$ \\ ${ }^{1}$ Dr. of Economic Sciences, Associate Professor, Associate Professor of the Department of Management and Civil \\ Service, Chernihiv Polytechnic National University, Ukraine, 95 Shevchenko Str., Chernihiv, 14035, Ukraine. Email: \\ popelo.olha@gmail.com
}

${ }^{2}$ Dr. of Economic Sciences, Professor, Professor of the Department of Economics and Entrepreneurship, National Technical University of Ukraine "Igor Sikorsky Kyiv Polytechnic Institute”, 37 Prosp. Peremohy, Kyiv, 03056, Ukraine. Email: tuha@ukr.net

${ }^{3}$ Dr. of Economic Sciences, Associate Professor, Head of the Department of Management and Public Administration, IHE “Academician Yuriy Bugay International Scientific and Technical University”, 3 lane Magnitogorsky, Kyiv, 02000, Ukraine.Email: r_istu@ukr.net

$4 \mathrm{PhD}$ in Economics, Associate Professor of the Department of Management and Public Administration, IHE "Academician Yuriy Bugay International Scientific and Technical University”, 3 lane Magnitogorsky, Kyiv, 02000, Ukraine.Email:felix@ukr.net

${ }^{5}$ Dr. of Economic Sciences, Associate Professor, Professor of the Department of Economics and Entrepreneurship, National Technical University of Ukraine “Igor Sikorsky Kyiv Polytechnic, Institute”, 37 Prosp. Peremohy, Kyiv, 03056, Ukraine.-mail: alla_grechko@ukr.net

Received 0704 2021; Accepted 13042021

\begin{abstract}
In the article the authors propose a methodical approach to modeling and forecasting the innovative activity of regional economic systems, as well as its testing on the example of Polish voivodships. The methodical involves the calculation of integrated indices of innovation activity of regions, taking into account the correlation analysis of evaluation indicators and calculations of coefficients of impact on the integrated index, which allows to predict the most influential indicators of innovation activity of regions and integrated index. For forecasting, a scenario approach is used, which provides an approximate approximation of the forecast parameter, which allows using two or three iterations to obtain a forecast of the integrated index of innovation activity of regional economic systems. The proposed methodological approach to forecasting the innovation activity of regions will help focus the efforts of regional authorities on the most influential factors of innovation activity of specific regional economic systems, which will achieve the goal of sustainable development based on innovative economic development of regions.
\end{abstract}

Keywords: innovation activity, integrated index, modeling, forecasting, region, regional economic system, sustainable development, voivodships.

JEL Codes: O30, O52, R11.

\section{Introduction}

Ensuring the achievement of sustainable development goals raises the issue of directing the innovative development of its regional economic systems, which requires a comprehensive study of innovation activity of regions and their forecasting, taking into account the most influential indicators

Copyright (C) 2021 Author(s), published by Vytautas Magnus University. This is an open access article distributed under the terms of the Creative Commons Attribution Non-Commercial 4.0 (CC BY-NC 4.0) license, which permits unrestricted use, distribution, and reproduction in any medium provided the original author and source are credited. The material cannot be used for commercial purposes. 
of each region. This will contribute to the development and implementation of a systems approach, taking into account the characteristics of the regions to increase their innovation activity. Forecasting innovation activity will promote the development of individual strategies by regional economic systems, taking into account those factors that will maximize their innovation activity. This, in turn, determines the relevance of research in modern processes of achieving sustainable development goals.

The purpose of this study is to develop a methodological approach to modeling and forecasting the innovation activity of regional economic systems, which will help identify the most influential indicators and develop measures to increase the innovation activity of regions. To achieve this goal were: analysis of existing developments in forecasting the innovative activity of regional economic systems; the scheme of forecasting of the integrated index of innovative activity of regional systems taking into account the most influential indicators is offered; the proposed methodological approach was tested on the example of Polish voivodeships.

The object of research is the innovative activity of regional economic systems. The subject of the study is the forecasting of innovation activity of voivodeshipson the basis of calculations of integrated indices of innovation activity and coefficients of influence of evaluation indicators on it.

The authors used general scientific techniques and special methods of scientific research, in particular, the method of analysis and synthesis to distinguish estimated indicators of innovation activity of regional economic systems, the method of generalizations and monographic in the study of existing methodological approaches to forecasting innovation activity of regions and index, method of economic analysis and modeling in the calculation and forecasting of innovation activity of regional economic systems.

The proposed methodological approach to modeling and forecasting innovation activity of regions by modeling the impact of the most influential indicators on the value of the integrated index will help focus on the most influential factors of innovation activity of specific regional economic systems, which will generally achieve sustainable development based on innovative development.

\section{Literature review}

Many scientific works of domestic and foreign scientists are devoted to research of innovative activity of regions and forecasting of the basic indicators of innovative development, including: Butko M. (2019); Duwe D., Herrmann F., Spath D. (2018); Hajek P., Henriques R., Castelli M., Vanneschi L. (2019); Iftikhar R., Khan M. S. (2020); Jankowska B., Matysek-Jędrych A., MroczekDabrowska K. (2017); Jia N. (2017); Kopaygorodsky A. (2020); Meliciani V., Savona M. (2015); Sandu I., Butorin S., Ryzhenkova N. (2018); Sudolska A., Łapińska J. (2020); Szopik-Depczynska K., Cheba K., WiSniewska J. (2020); Tokunaga S., Okiyama M. (2017); Zajkowska M. (2017).

Hajek P., Henriques R., Castelli M., Vanneschi L. (Czech Republic, Portugal) consider that the innovation indicators of regional innovation systems can serve as an important tool for policy development to identify best practices and provide assistance to regions in need. The main purpose of the article is to develop a model based on the variant of genetic programming to solve the problem of regional forecasting of innovation indicators (Hajek et al., 2019).

The scientific work of Iftikhar R., Khan M.S. (Ireland, Zealand) presents an innovative approach to improving demand forecasting in the supply chain using social media data from Twitter and Facebook. The forecasting structure was tested on the basis of a case study in the retail supply chain. It is concluded that the proposed forecasting system has a positive effect on improving the accuracy of forecasting demand in the supply chain (Iftikhar R. et al., 2020).

The study of Kopaygorodsky A. is devoted to the application of natural language processing methods to support research and forecast the innovative development of energy infrastructure. Scientists have considered the 
Management Theory and Studies for Rural Business and Infrastructure Development

eISSN 2345-0355. 2021. Vol. 43. No. 2: 307 - 315

Article DOI: https://doi.org/10.15544/mts.2021.27

main methods of NLP, which are used to build an intelligent system to support research (Kopaygorodsky, 2020).

The article by scientists Sandu I., Butorina S., Ryzhekova N. considers the concept of the need to change approaches in forecasting the innovative development of the agricultural sector of the Perm region with the requirements of digitalization of the economy and management of innovation processes. The factors that ensure the management of innovative activities of enterprises and organizations operating in the agricultural sector of the economy are considered. A model for forecasting the innovative development of the agricultural sector of the region's economy is proposed (Sandu, et al., 2018).

The article by Tokunaga S. and Okiyami M. from Japan uses an innovative dynamic two-regional computational model of common equilibrium. They developed scenarios for each of these two clusters and assessed the economic impact of each new industry cluster model on catastrophe regions (Tokunaga S. et al., 2017).

The article of scientists Meliciani V., Savona M. (Italy, France) accounts for the determinants of sectoral specialization in business services across the EU-27 regions as determined by: agglomeration economies, the region-specific structure of intermediate linkages, technological innovation and information intensity and the presence of these factors in neighboring regions. Their findings indicate that, besides urbanization economies, the spatial structure of intermediate sectoral linkages and innovation, in specific Information and Communication Technologies (ICTs), are necessary determinants of specialization in business services (Meliciani et al., 2015).

The main purpose of the research conducted by Polish scientists SzopikDepczynska K., Cheba K., WiSniewska I. is to identify internal and external factors that encourage the relevant Polish research and development departments to take an active part in innovation, $\mathrm{R} \& \mathrm{D}$ and user-oriented innovation. Econometric models were used to study the relationship between the selected determinants. The results of the study confirmed that it is important to invest in innovation, but it is especially important to have a strategy for research and development in the enterprise (Szopik-Depczynska et al., 2020).

The main objective of the article of Zojkowska M. (Poland) is to analyze the possibilities of applying open innovation models in the management of micro, small, and medium enterprises (SMEs) in Poland. The article is based on a study the essence of open innovations in terms of values, their origin and conditions for implementation in the management process, which is typical for the SME sector. The study was based on in-depth semi-structured interviews conducted among business leaders / owners responsible for the innovative development of SMEs in Poland (Zajkowska, 2017).

The purpose of the paper of Polish scientists Jankowska B., Matysek-Jędrych A. is to explain how national innovation systems can transform the innovation contribution into innovation output in different countries. The research question is based on the assumption that the greater the contribution to innovation, the higher the amount of innovation achieved by the country. They use cluster analysis to test assumptions. Using a cross-comparison method, they seek to test how and why national innovation systems have failed (or succeeded) in creating innovation (Jankowska et al., 2017).

Chinese scientist Jia N. examines the impact of corporate innovation strategy on analytical activities and forecasting results, as well as the economic consequences associated with it. The researcher examines how innovation strategy affects analysts'

Copyright (C) 2021 Author(s), published by Vytautas Magnus University. This is an open access article distributed under the terms of the Creative Commons Attribution Non-Commercial 4.0 (CC BY-NC 4.0) license, which permits unrestricted use, distribution, and reproduction in any medium provided the original author and source are credited. The material cannot be used for commercial purposes. 
confidence in forecasts, and finds that investors appear to be less sensitive to revisions to forecasts issued to research firms (Jia, 2017).

The article by Polish scientists A. Sudolska and J. Lapinska is aimed at determining the factors that determine the innovative capacity of Polish manufacturing enterprises. The empirical contribution of the article is to recognize the relationship between certain practices used by Polish manufacturing companies and their innovative capacity, measured by innovation activity. (Sudolska et al., 2020).

German scientists Duwe D., Herrmann F., Spath D. claim that the forecast of the spread of innovative technologies and, in particular, the turning point after which they penetrate the market, is of paramount importance for both new and established companies. Research has answered the question of how to identify technological change, but the timing of technological change remains unresolved (Duwe et al., 2018).

\section{Methodical approach}

To forecast the innovation activity of the regions on the example of Polish voivodeships, we will use the correlation of the analyzed variables, which we used to analyze the innovative activity of voivodeships. The sample of input data for modeling should correspond to the laws of pairwise correlation by which $|\mathrm{k}| \leq 0.7$. For estimates representing the elements of the correlation matrix $\mathrm{K}=\|\mathrm{kxv}\|$, where respectively:

$$
K_{x v}=\frac{\operatorname{cov}(x v)}{D\left[x v_{2}\right]}
$$

where cov (xv) - covariance between samples of estimated variables $x v$;

$D\left[x v_{2}\right]$ - the corresponding variances of variables that are not equal to zero.

Carrying out of the correlation analysis of estimation indicators gives the chance to substantiate not only legality of their definition, but also to continue calculations and to define the most influential indicators as an integral index of innovative activity. In further calculations by the method of multiple regression, the mathematical and statistical formalization of the problem for finding the integral index is carried out. Since the construction of a pairwise correlation between variable estimates makes it possible to avoid the facts of simultaneity ( $r \geq 0.7)$, it makes it possible to use such a modeling tool as multiple regression to determine the impact factors, weights are regression coefficients that characterize the econometric factor, and namely the integral index.

Representing the indices by writing a pair of numbers $\left\langle a, r_{a}\right\rangle$ we find the interval $\left[a-r_{a}, a+r_{a}\right]$, the boundaries of which can be modeled using linear prediction. For calculations of the average integral index, a multidimensional sequence of observations was chosen from the statistical data of the estimated indicators $\mathrm{x}_{1}, \mathrm{x}_{2}, \mathrm{x}_{3}, \mathrm{x}_{4} 3$ 2010-2019. Due to econometric modeling, we move from the given correlated features $x(1), x(2), x(3)$, $x(4)$, which are components of observations for each of the voivodeships $(\mathrm{v}=16)$, to the signs of coefficients of influence.

To predict, we find an estimate of the unknown loads $\widehat{q_{\imath \jmath}}$, residual variances $\widehat{v_{\imath \jmath}}$, and identify factors within the calculated intervals $\widehat{f}^{\imath}$ finding the objective functions in the form of sums with a certain approximation in the form $\widehat{f^{(x)}}$. Since the estimates as a result of their rationing are homogeneous, we use the form of the objective function as a linear estimate of variables in the form:

$$
\hat{f}(X ; \theta)=\theta_{0}+\sum_{i=1}^{v} \theta_{i} x^{(i)}
$$

where $\quad \theta=\left(\theta_{0}, \theta_{1}, \ldots, \theta_{v},\right)^{\mathrm{T}}$ regression parameters determined from the estimated indicators for each of the voivodeships.

For forecasting, a scenario approach is used, which assumes an approximate approximation of the forecast parameter, the result of which corrects the initial approximation. The algorithm for forecasting is presented in Fig. 1.

To calculate the integrated index, the following indicators of innovation activity were used:

- firstly, $X_{1}$ - the number of industrial enterprises that have implemented innovations (units); 
- secondly, $\mathrm{X}_{2}$ - the volume of sold innovative products per capita (euro);

- thirdly, $X_{3}$ - the volume of sold innovative products in $\%$ to the total volume of sold industrial products (\%).

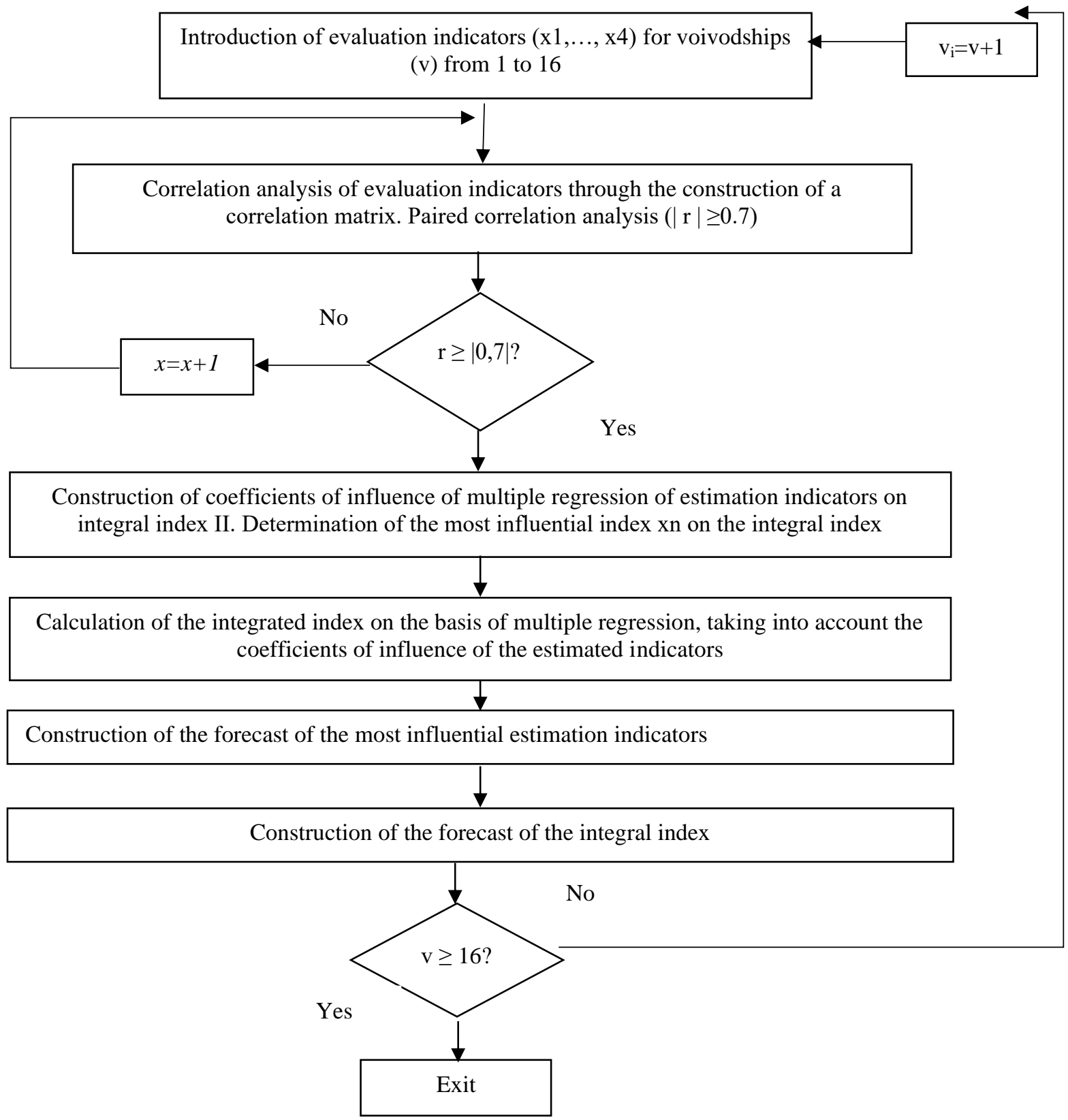

\section{Figure 1. Scheme of forecasting the integrated index of innovation activity of voivodships taking into account the most influential indicators}

(Developed by the authors)

Copyright (C) 2021 Author(s), published by Vytautas Magnus University. This is an open access article distributed under the terms of the Creative Commons Attribution Non-Commercial 4.0 (CC BY-NC 4.0) license, which permits unrestricted use, distribution, and reproduction in any medium provided the original author and source are credited. The material cannot be used for commercial purposes. 


\section{Results}

The results of calculations according to the presented forecasting algorithm when testing the methodological approach for the voivodships of Poland are given in table 1.

Table 1. The value of the integrated index of innovation activity of Polish voivodships

(Developed by the authors)

\begin{tabular}{|c|c|c|c|c|c|}
\hline Voivodeship & $\begin{array}{l}\text { The average } \\
\text { value of the } \\
\text { integrated } \\
\text { index for } \\
2010-2019\end{array}$ & $\begin{array}{l}\text { The rank of the } \\
\text { voivodship } \\
\text { according to the } \\
\text { average } \\
\text { integrated index }\end{array}$ & $\begin{array}{c}\text { Grouping of } \\
\text { voivodships by } \\
\text { the level of value } \\
\text { of the average } \\
\text { integrated index }\end{array}$ & \begin{tabular}{|c|} 
The most \\
influential \\
indicator in the \\
calculation of \\
the integrated \\
index
\end{tabular} & $\begin{array}{l}\text { The average growth } \\
\text { of the forecast value } \\
\text { of the average } \\
\text { integrated index } \\
\text { under the dominant } \\
\text { of the most } \\
\text { influential indicator }\end{array}$ \\
\hline Warmia and Mazury & 0,344 & 14 & Low & $\mathrm{X}_{1}$ & 0,011 \\
\hline Greater Poland & 0,805 & 4 & High & $\mathrm{X}_{2}$ & 0,021 \\
\hline West Pomeranian & 0,430 & 10 & Low & $\mathrm{X}_{3}$ & 0,017 \\
\hline Kujawsko-Pomorskie & 0,506 & 9 & Average & $\mathrm{X}_{2}$ & 0,015 \\
\hline Lodzkie & 0,594 & 7 & Average & $\mathrm{X}_{1}$ & 0,008 \\
\hline Lublin & 0,370 & 13 & Low & $\mathrm{X}_{3}$ & 0,006 \\
\hline Lubuskie & 0,387 & 12 & Low & $\mathrm{X}_{3}$ & 0,005 \\
\hline Masovian & 0,853 & 2 & High & $\mathrm{X}_{2}$ & 0,019 \\
\hline Lesser Poland & 0,733 & 5 & High & $\mathrm{X}_{2}$ & 0,010 \\
\hline Lower Silesian & 0,652 & 6 & Average & $\mathrm{X}_{1}$ & 0,014 \\
\hline Opole Province & 0,390 & 11 & Low & $\mathrm{X}_{3}$ & 0,014 \\
\hline Podkarpackie Province & 0,582 & 8 & Average & $\mathrm{X}_{2}$ & 0,014 \\
\hline Podlasie & 0,325 & 15 & Low & $\mathrm{X}_{3}$ & 0,012 \\
\hline Pomeranian & 0,855 & 1 & High & $\mathrm{X}_{3}$ & 0,014 \\
\hline Swietokrzyskie & 0,321 & 16 & Low & $\mathrm{X}_{1}$ & 0,012 \\
\hline Silesian & 0,848 & 3 & High & $\mathrm{X}_{2}$ & 0,013 \\
\hline $\begin{array}{l}\text { The arithmetic mean } \\
\text { value of the integrated } \\
\text { index by voivodships }\end{array}$ & 0,563 & - & - & & \\
\hline
\end{tabular}

Regarding the grouping of voivodeships by the value of the average integrated index, it should be noted that their grouping was carried out according to the interval between the highest value of the average integrated index of Pomeranian (0.855) and the lowest value of the average integrated index of Swietokrzyskie (0.321). As a result of this grouping, a group with a high level of innovation activity was obtained, which included five voivodeships: Pomeranian, Masovian, Silesian, Greater Poland and Lesser Poland.

The group with the average value of the average integrated index includes four voivodships: Lower Silesian, Lodzkie, Podkarpackie Province, and KujawskoPomorskie. At the same time, seven other voivodeships belong to the most numerous group in terms of the value of the average integrated index.

When calculating the integrated index, the calculation of the impact factor was used, which made it possible to determine the most influential indicator on the value of the integrated index. According to the results of the calculation for the four voivodships, the most influential indicator is the number of industrial enterprises that have implemented innovations, such voivodeships include: Warmia and Mazury, Lodzkie, Lower Silesia and Swietokrzyskie. It should also be noted that all voivodships belong to the regions with a medium or low level of the integrated index. 
The volume of sold innovative products per capita is the most important indicator for six voivodeships, namely: Greater Poland, Kujawsko-Pomorskie, Masovian, Lesser Poland, Podkarpackie Province and Silesian. All these regions belong to enterprises with a high or medium value of the integrated index.

The most influential indicator is the volume of sold innovative products as a percentage of the total volume of sold industrial products for such voivodships as: West Pomeranian, Lublin, Lubuskie, Opole Province, Podlasie and Pomeranian.

The volume of sold innovative products as a percentage of the total volume of sold industrial products is the most influential indicator in the calculations of the integrated index of all six other voivodships, including: West Pomeranian, Lublin, Lubuskie, Opole
Province, Podlasie and Pomeranian. All these voivodeships, except for the Pomeranian, belong to the regions with a low level of value of the average integrated index.

Table 2 presents the results of predictive values of the most influential indicators of the proposed approach. The presented results of forecasting the most influential indicators make it possible to note that different voivodships in the forecast period have different growth dynamics of indicators. For example, the most influential indicator, namely the number of industrial enterprises that implemented innovations (X1) for Warmia and Mazury for the forecast period until 2030 has a projected increase of 1.13 times, and for Lodzkie the increase of the most influential indicator will be 1.24 .

\section{Table 2. Forecast of the most influential indicators according to the proposed methodological approach for the voivodships of Poland}

(Developed by the authors)

\begin{tabular}{|l|c|c|c|c|c|c|c|c|c|c|c|}
\hline \multirow{2}{*}{ Voivodeship } & \multicolumn{10}{|c|}{ Forecast period } \\
\cline { 2 - 15 } & 2020 & 2021 & 2022 & 2023 & 2024 & 2025 & 2026 & 2027 & 2028 & 2029 & 2030 \\
\hline Warmia and Mazury & 208 & 211 & 214 & 216 & 219 & 222 & 224 & 227 & 230 & 232 & 235 \\
\hline Greater Poland & 2800,1 & 2800,1 & 2805,7 & 2814,1 & 2819,7 & 2828,1 & 2833,7 & 2842,1 & 2840,0 & 2839,6 & 2837,2 \\
\hline West Pomeranian & 4,4 & 4,4 & 4,2 & 4,1 & 4,6 & 4,6 & 4,6 & 4,7 & 4,7 & 4,7 & 4,7 \\
\hline Kujawsko-Pomorskie & 1125,9 & 1109,0 & 1120,3 & 1122,5 & 1124,8 & 1137,2 & 1147,3 & 1134,8 & 1137,6 & 1126,5 & 1131,9 \\
\hline Lodzkie & 482 & 493 & 505 & 516 & 527 & 539 & 550 & 562 & 573 & 585 & 596 \\
\hline Lublin & 6,14 & 6,12 & 6,16 & 6,2 & 6,21 & 6,26 & 6,32 & 6,32 & 6,38 & 6,39 & 6,44 \\
\hline Lubuskie & 13,24 & 12,55 & 13,24 & 13,24 & 13,24 & 13,24 & 13,24 & 15,31 & 16,00 & 16,00 & 17,39 \\
\hline Masovian & 2003,6 & 2023,6 & 2043,6 & 2061,7 & 2081,7 & 2101,7 & 2121,8 & 2118,6 & 2119,7 & 2119,7 & 2120,5 \\
\hline Lesser Poland & 1986,7 & 2068,2 & 2149,6 & 2231,1 & 2312,5 & $23,92,0$ & 2473,5 & 2542,6 & 2531,1 & 2507,5 & 2494,6 \\
\hline Lower Silesian & 2040,6 & 2054,9 & 2054,9 & 2071,2 & 2085,5 & 2099,7 & 2116,1 & 21304,5 & 21303,9 & 21321 & 2099,9 \\
\hline Opole Province & 8,43 & 8,59 & 8,74 & 8,90 & 9,06 & 9,23 & 9,38 & 9,54 & 9,70 & 9,85 & 10,01 \\
\hline Podkarpackie Province & 1386,5 & 1415,6 & 1446,1 & 1475,2 & 1504,4 & 1533,5 & 1564,0 & 1560,2 & 1542,6 & 1552,9 & 1501,6 \\
\hline Podlasie & 6,61 & 6,76 & 63,90 & 7,04 & 7,18 & 7,33 & 7,46 & 7,61 & 7,76 & 7,89 & 8,04 \\
\hline Pomeranian & 21,08 & 21,17 & 21,25 & 21,36 & 21,44 & 21,53 & 21,61 & 21,69 & 21,78 & 21,88 & 21,97 \\
\hline Swietokrzyskie & 165 & 167 & 169 & 172 & 174 & 176 & 178 & 180 & 183 & 185 & 187 \\
\hline Silesian & 2830,0 & 2849,8 & 2869,6 & 2892,3 & 2912,1 & 2931,9 & 2951,7 & 2959,2 & 2947,5 & 2946,1 & 2924,8 \\
\hline
\end{tabular}

On the basis of calculations of forecast values of the most influential indicators calculations of integrated indices for the period from 2020-2030 were carried out. Results of the forecast of integrated indices of innovative activity of voivodships according to the

Copyright (C) 2021 Author(s), published by Vytautas Magnus University. This is an open access article distributed under the terms of the Creative Commons Attribution Non-Commercial 4.0 (CC BY-NC 4.0) license, which permits unrestricted use, distribution, and reproduction in any medium provided the original author and source are credited. The material cannot be used for commercial purposes. 
offered methodical approach are presented in table. 3 .

Table 3. Forecast of integrated indices of innovation activity of voivodships according to the proposed methodological approach for voivodships of Poland

(Developed by the authors)

\begin{tabular}{|c|c|c|c|c|c|c|c|c|c|c|c|c|}
\hline \multirow[b]{2}{*}{ Voivodeship } & \multicolumn{12}{|c|}{ Forecast period } \\
\hline & 2020 & 2021 & 2022 & 2023 & 2024 & 2025 & 2026 & 2027 & 2028 & 2029 & 2030 & $\begin{array}{c}\text { The averag } \\
\text { value of the } \\
\text { forecast } \\
\text { index }\end{array}$ \\
\hline Warmia and Mazury & 0,353 & 0,365 & 0,374 & 0,364 & 0,374 & 0,363 & 0,363 & 0,373 & 0,373 & 0,362 & 0,357 & 0,366 \\
\hline Greater Poland & 0,817 & 0,852 & 0,852 & 0,852 & 0,848 & 0,848 & 0,848 & 0,848 & 0,848 & 0,848 & 0,836 & 0,845 \\
\hline West Pomeranian & 0,429 & 0,449 & 0,461 & 0,472 & 0,484 & 0,476 & 0,476 & 0,476 & 0,464 & 0,454 & 0,444 & 0,462 \\
\hline Kujawsko-Pomorskie & 0,522 & 0,535 & 0,536 & 0,537 & 0,538 & 0,539 & 0,538 & 0,540 & 0,540 & 0,522 & 0,540 & 0,535 \\
\hline \begin{tabular}{|l|l|} 
Lodzkie & \\
\end{tabular} & 0,581 & 0,590 & 0,599 & 0,608 & 0,627 & 0,626 & 0,625 & 0,619 & 0,615 & 0,614 & 0,605 & 0,610 \\
\hline Lublin & 0,376 & 0,378 & 0,381 & 0,381 & 0,381 & 0,385 & 0,387 & 0,387 & 0,387 & 0,384 & 0,376 &, 382 \\
\hline Lubuskie & 0,392 & 0,389 & 0,392 & 0,392 & 0,392 & 0,393 & 0,393 & 0,392 & 0,400 & 0,403 & 0,403 & 0,395 \\
\hline Masovian & 0,869 & 0,898 & 0,897 & 0,901 & 0,900 & 0,889 & 0,888 & 0,887 & 0,887 & 0,886 & 0,875 & 0,889 \\
\hline Lesser Poland & 0,737 & 0,745 & 0,748 & 0,751 & 0,760 & 0,763 & 0,761 & 0,759 & 0,757 & 0,756 & 0,749 & 0,753 \\
\hline Lower Silesian & 0,661 & 0,671 & 0,672 & 0,674 & 0,665 & 0,674 & 0,681 & 0,682 & 0,682 & 0,683 & 0,673 & 0,674 \\
\hline Opole Province & 0,403 & 0,424 & 0,425 & 0,416 & 0,417 & 0,419 & 0,420 & 0,416 & 0,417 & 0,418 & 0,404 & 0,416 \\
\hline $\begin{array}{l}\text { Podkarpackie } \\
\text { Province }\end{array}$ & 0,590 & 0,596 & 0,602 & 0,608 & 0,609 & 0,615 & 0,616 & 0,618 & 0,609 & 0,610 & 0,603 & 0,607 \\
\hline Podlasie & 0,337 & 0,342 & 0,348 & 0,353 & 0,354 & 0,349 & 0,350 & 0,355 & 0,356 & 0,346 & 0,332 & 0,347 \\
\hline Pomeranian & 0,857 & 0,866 & 0,876 & 0,885 & 0,885 & 0,894 & 0,894 & 0,883 & 0,883 & 0,882 & 0,881 & 0,881 \\
\hline Swietokrzyskie & 0,336 & 0,345 & 0,345 & 0,350 & 0,349 & 0,349 & 0,344 & 0,343 & 0,343 & 0,342 & 0,330 & 0,343 \\
\hline Silesian & 0,860 & 0,872 & 0,877 & 0,876 & 0,881 & 0,876 & 0,875 & 0,880 & 0,875 & 0,875 & 0,860 & 0,873 \\
\hline
\end{tabular}

\section{Conclusions}

Activation of innovation of regional economic systems presupposes the development of independent, specific ways taking into account the peculiarities of regional economic systems based on identifying the most influential indicators to increase the innovation activity of a particular regional innovation system and their forecasting. In the proposed methodological approach to forecasting the integrated index of innovation activity, taking into account the impact of the most influential indicators, correlation and regression analysis were used to estimate the calculation of the integrated index, multiple regression and linear forecasting.

The proposed methodological approach was tested on the example of Polish voivodships. The obtained calculations make it possible to conclude that the regions have different integrated indices. Thus, in relation to the average integrated index between the Pomeranian Voivodeship, which occupies the highest level, and Swietokrzyskie, which occupies the last step, it is 2.7 times.

This approach to forecasting, taking into account the most influential indicators, makes it possible to increase the accuracy of forecast values, as well as to focus the attention of local authorities of regional economic systems on improving those economic indicators that have the greatest impact on innovation activity of regional systems. 


\author{
Management Theory and Studies for Rural Business and Infrastructure Development \\ eISSN 2345-0355. 2021. Vol. 43. No. 2: 307 - 315 \\ Article DOI: https://doi.org/10.15544/mts.2021.27
}

\title{
References
}

Butko, M., Popelo, O., Pishenin, I. (2019). Innovations in Human Resources Management in Eurointegration Conditions: Case for Ukrainian Agro-industrial Complex. Marketing and management of innovations, 2, pp. 74-82.

Duwe, D., Herrmann, F., Spath, D. (2018). Forecasting the diffusion of product and technology innovations: Using google trends as an example. 2018 Portland International Conference on Management of Engineering and Technology, PICMET 2018. 8481971.

Hajek, P., Henriques, R., Castelli, M., Vanneschi, L. (2019). Forecasting performance of regional innovation systems using semantic-based genetic programming with local search optimizer. Computers and Operations Research, 106, pp. 179-190.

Iftikhar, R., Khan, M. S. (2020). Social media big data analytics for demand forecasting: Development and case implementation of an innovative framework. Journal of Global Information Management, 28(1), pp. 103-120.

Jankowska, B., Matysek-Jędrych, A., Mroczek-Dabrowska, K. (2017). Efficiency of National Innovation Systems - Poland and Bulgaria in the Context of the Global Innovation Index. Comparative Economic Research, 20(3), pp. 77-94.

Jia, N. (2017). Corporate Innovation Strategy, Analyst Forecasting Activities and the Economic Consequences. Journal of Business Finance and Accounting, 44(5-6), pp. 812-853.

Kopaygorodsky, A. (2020). Natural Language Processing for Forecasting Innovative Development of the Energy Infrastructure. Web of Conferences, 209, 030152020.

Meliciani, V., Savona, M. (2015). The determinants of regional specialisation in business services: Agglomeration economies, vertical linkages and innovation. Journal of Economic Geography, 15(20), pp. $387-416$.

Sandu, I., Butorin, S., Ryzhenkova, N. (2018). Scientific basis for forecasting the innovative development of the agricultural sector of the region's economy (on the materials of the Perm region). IOP Conference Series: Earth and Environmental Science, 274(1), 012016.

Sudolska, A., Łapińska, J. (2020). Exploring determinants of innovation capability in manufacturing companies operating in Poland. Sustainability, 12(17), 7101.

Szopik-Depczynska, K., Cheba, K., WiSniewska, J.(2020). Innovation, R\&D and user-driven innovation activity in R\&D Departments in Poland. 24th KES International Conference on Knowledge-Based and Intelligent Information and Engineering Systems, KES 2020, 176, pp. 2705-2713.

Tokunaga, S., Okiyama, M. (2017). Impacts of industry clusters with innovation on the regional economy in Japanese depopulating society after the Great East Japan Earthquake. Asia-Pacific Journal of Regional Science, 1(1), pp. 99-131.

Zajkowska, M. (2017). Open models of innovation processes as a future management challenge for small and medium-sized enterprises in Poland. Journal of Management and Business Administration. Central Europe, 25(4), pp. 193-208.

Copyright (C) 2021 Author(s), published by Vytautas Magnus University. This is an open access article distributed under the terms of the Creative Commons Attribution Non-Commercial 4.0 (CC BY-NC 4.0) license, which permits unrestricted use, distribution, and reproduction in any medium provided the original author and source are credited. The material cannot be used for commercial purposes. 